\title{
PENGEMBANGAN SISTEM PENDUKUNG KEPUTUSAN PENGENDALIAN PERSEDIAAN BARANG MENGGUNAKAN METODE ECONOMIC ORDER QUANTITY (EOQ) DAN MIN-MAX BERBASIS WEB (STUDI KASUS : APOTEK SAHABAT QITA)
}

\author{
Gde Gung Prabawa ${ }^{1}$, I Gede Mahendra Darmawiguna ${ }^{2}$, I Made Agus Wirawan ${ }^{3}$ \\ 1, 2, 3 Pendidikan Teknik Informatika, Universita Pendidikan Ganesha \\ Singaraja-Bali, Indonesia
}

e-mail: gungprabawa85@gmail.com ${ }^{1}$, mahendra.darmawiguna@undiksha.ac.id ${ }^{2}$, imade.aguswirawan@undiksha.ac.id ${ }^{3}$

\begin{abstract}
Abstrak
Pengendalian persediaan barang sangat penting diperhitungkan karena kekurangan atau kelebihan persediaan merupakan faktor yang memicu peningkatan biaya. Kelebihan persediaan akan membuat biaya yang dikeluarkan menjadi lebih besar dan beresiko kerusakan atau kadaluarsa, sedangkan jika persediaan barang sedikit akan beresiko terhadap permintaan yang tidak terpenuhi sehingga akan mengalami penurunan biaya pendapatan. Penelitian ini dikembangkan sejalan dengan masalah yang sering dihadapi di Apotek Sahabt Qita. Melihat hal tersebut dikembangkan suatu sistem pendukung keputusan pengendalian persediaan barang dengan menggunakan metode EOQ (Economix Order Quantity) dan Min-Max. Keunggalan dari metode EOQ ini yaitu menentukan jumlah pemesanan persediaan yang ekonomis dengan penyelesaian cepat, sedangkan metode Min-max dapat mengendalikan persediaan barang maksimal dan minimal sekaligus sebagai waktu untuk melakukan pemesanan. Dari hasil pengujian sistem, didapatkan hasil bahwa secara umum sistem mampu membantu merekomendasikan dan mendukung pengambilan keputusan dalam menentukan kebijakan jumlah pemesanan, persediaan maksimum dan persediaan minimum sehingga dapat mengoptimalkan biaya.
\end{abstract}

Kata kunci: sistem pendukung keputusan, pengendalian persediaan, jumlah pemesanan, jumlah persediaan maksimum dan minimum, metode EOQ (Economic Order Quantity), metode Min-Max.

\begin{abstract}
Inventory control is very important because the shortage or excess inventory is a factor that triggers an increase in cost. Excess inventory will make the cost incurred to be greater and risk of damage or expiration, whereas if a small inventory of goods will be at risk to unmet demand that will decrease the cost of income. This research is developed in line with the problems often faced at the Sahabat Qita pharmacy. Seeing this developed a decision support system inventory control by using methods EOQ (Economix Order Quantity) and Min-Max. The uniqueness of this EOQ method is to determine the amount of economical supply ordering with quick settlement, while the Min-max method can control the inventory of goods maximum and minimum as well as time to place an order. From the results of testing the system capable to help consider and determine the policy amount of ordering, maximum inventory and minimum inventory so as to optimize costs.
\end{abstract}

Keywords : Decision Support System, EOQ method (Economic Order quantity), inventory control, maximum and minimum inventory amount, Min-Max method, order amount 


\section{PENDAHULUAN}

Pengendalian persediaan barang merupakan suatu bagian yang terpenting dalam menjalankan suatu usaha. Persediaan merupakan sumber daya ekonomi yang perlu diadakan dan sisimpan untuk menunjang penyelesaian pengerjaan suatu produk [1]. Pengendalian persediaan barang dapat diterapkan di berbagai bidang usaha, terutama pada bidang usaha yang memiliki banyak jenis barang seperti apotek. Apotek merupakan salah satu jenis usaha dibidang perobatan yang memilki banyak jenis barang (obat) sehingga perlu adanya pengendalian persediaan dan pengolahan data untuk mempermudah dan memperlancar kegiatan apotek. Apotek Sahabat Qita adalah salah satu apotek di daerah Tamanbali Bangli. Apotek sahabat kita dalam melakukan proses pengolahan data masih dilakukan secara manual yaitu pencatatan transaksi dan data barang ke dalam buku besar. Berdasarkan hasil observasi dan wawancara yang telah dilakukan di Apotek Sahabat Qita terdapat beberapa permasalahan. Masalah pengambilan keputusan terutama penentuan jumlah barang yang dibeli pada periode mendatang dan penyediaan stok barang merupakan permasalahan yang sering dihadapi. Stok barang yang banyak dan pencatatan yang manual menyulitkan melakukan pengecekan stok barang. Dalam penyediaan stok barang perlu diperhitungkan barang pengaman karena pegawai dan pemilik apotek pernah mengalami keterlambatan datangnya barang yang sudah diorder, sehingga pernah mengalami kehabisan persediaan barang sebelum barang yang dipesan datang.

Untuk mengatasi masalah dan kendala ini perlu dikembangkan suatu sistem pendukung keputusan pengendalian persediaan barang yang menyajikan informasi persediaan barang dan pengolahan data. Sistem pendukung keputusan merupakan suatu sistem interaktif yang mendukung keputusan dalam proses pengambilan keputusan melalui informasi-informasi yang diperoleh dari hasil pengolahan data [2].

Sistem pendukung keputusan dalam pengendalian persediaan barang dapat dikembangkan dengan metode EOQ (Economic Order Quantity). EOQ merupakan volume atau jumlah pembelian yang paling ekonomis untuk dilaksanakan pada setiap kali pemesanan [3]. Keunggulan metode ini adalah waktu penyelesaian yang relative lebih cepat dan hasil yang mendekati nilai optimal [4]. Kelemahan EOQ adalah EOQ mengasumsi data bersifat tetap dan persediaan pengaman tidak diperhitungkan [5]. Untuk meminimkan kelemahan tersebut digunakanlah metode Min- Max. Metode Min-Max adalah metode yang memperhitungkan persediaan pengaman. Konsep persediaan minimum dan maksimum tidak berdasarkan perhitungan secara berkala tetap, tetapi dapat dilakukan setiap waktu, dengan konsep titik pemesanan kembali atau reorder point [5]. Dengan mengembangkan sistem pendukung keputusan dengan metode EOQ dan Min-Max diharapkan mampu mengoptimalkan persediaan barang dan biaya persediaan.

Berdasarkan latar belakang diatas, maka penulis tertarik untuk melakukan penelitian dengan judul "Pengembangan Sistem Pendukung Keputusan Pengendalian Persediaan Barang Menggunakan Metode Economic Order Quantity (EOQ) dan Min- Max" Berbasis Web Studi Kasus Apotek Sahabat Qita.

\section{Kajian Teori}

\section{A. EOQ (Economic Order Quantity)}

$E O Q$ adalah sebuah perhitungan dengan rumus mengenai berapa jumlah, atau frekuensi pemesanan, atau nilai pemesanan yang paling ekonomis [5]. EOQ sebenarnya merupakan volume atau jumlah pembelian yang paling ekonomis untuk dilaksanakan pada setiap kali pemesanan [3].

Konsep perhitungan atas dasar jumlah pemesanan ekonomis atau Economic 
Order Quantity (EOQ) ini didasarkan atas pemikiran yang cukup logis dan sederhana sebagai berikut. Semakin sering pengisian kembali persediaan itu dilakukan, persediaan rata-rata akan semakin kecil dan ini berakibat bahwa biaya dalam bentuk biaya penyediaan barang akan semakin kecil juga. Tetapi di lain pihak, semakin sering pengisian kembali persediaan itu dilakukan, maka biaya pemesanan akan semakin besar pula.

Metode EOQ dapat dilaksanakan apabila kebutuhan-kebutuhan permintaan pada masa yang akan datang memiliki jumlah yang konstan dan relatif memiliki fluktuasi perubahan yang sangat kecil. Apabila jumlah permintaan dan masa tenggang diketahui, maka dapat diasumsikan bahwa jumlah permintaan dan masa tenggang merupakan bilangan yang konstan dan diketahui. Untuk memenuhi kebutuhan itu maka dapat diperhitungkn cara pemenuhan kebutuhannya (pembeliannya) yang paling ekonomis. Pada hakekatnya menajemen persediaan barang dengan kendala mengakui pedoman pengambilan keputusan yaitu [3] :

1. Kebutuhan setiap kali pesan.

2. Banyaknya satuan tiap pesanan

3. Biaya simpan

4. Biaya Pesan

Berdasarkan pemikiran tersebut, timbul formula EOQ untuk pemesanan persediaan yang paling ekonomis, yaitu sebagai contoh sebagai berikut :

Keterangan :

$$
\mathrm{EOQ}=\frac{\sqrt{2 S D}}{H}
$$

$S=$ Biaya orde tiap kali pesan

$\mathrm{D}=$ Jumlah kebtuhan periode tertentu

$\mathrm{H}=$ Biaya penyimpanan per unit

Metode EOQ adalah metode persediaan ekonomis, namun memiliki beberapa kelemahan. Kelemahan EOQ adalah EOQ mengasumsi data bersifat tetap dan persediaan pengaman tidak diperhitungkan [5].

\section{B. Min-Max}

Metode Min-Max metode dengan konsep persediaan minimum dan maksimum tidak berdasarkan perhitungan secara berkala tetap, tetapi dapat dilakukan setiap waktu, dengan konsep titik pemesanan kembali atau reorder point dan memperhitungkan persediaan pengaman [5]. Konsep Min-Max dikembangkan berdasarkan suatu pemikiran sederhana yaitu :

1. Untuk menjaga kelangsungan beroperasinya suatu pabrik atau fasilitas lain, diperlukan bahwa jenis material tertentu dalam jumlah minimum tersedia di gudang, supaya sewaktu-waktu ada yang rusak, dapat langsung diganti.

2. Tetapi material yang disimpan dalam persediaan tadi juga jangan terlalu banyak, ada maksimumnya, supaya biaya tidak menjadi terlalu mahal.

3. Kedunya sebetulnya pengikut prinsip inventory control yaitu pengendalian tingkat persediaan sedemkian rupa sehingga setiap kali barang diperlukan, selalu tersedia, tetapi sekaligus juga harus menjaga agar tingkat persediaan seminimal mungkin, untuk menghindari investasi berupa biaya penyediaan yang besar.

Secara ideal, sebetulnya persediaan minimum seharusnya adalah nol dan persediaan maksimum adalah sebanyak yang secara ekonomis mencapai optimal, yaitu sesuai dengan perhitungan EOQ. Jadi dapat dibayangkan bahwa persis pada waktu barang habis, pemesanan barang sejumlah yang paling ekonomis tadi datang. Tetapi ini perhitungan teori, artinya dalam kenyataan tidaklah dapat dijamin bahwa perencanaan dapat secara sempurna terpenuhi. Ada kemungkinan pemakaian barang berubah dan meningkat secara mendadak, ada kemungkinan barang yang dipesan datang terlambat dan sebagainya. Oleh karena dalam menentukan minimum dan maksimum ini, sebaiknya tidak mengambil angka yang ekstrim tadi, tetapi ada faktor pengaman yang dapat dihitung berdasarkan pengalaman [5]. Dengan demikian metode Min-Max harus diberengi dengan faktor faktor lainnya yaitu faktor pengaman yang 
dapat dihitung berdasarkan pengalaman. Berdasarkan pemikiran tersebut, timbul formula Min- Max untuk pengisian kembali persediaan, yaitu sebagai contoh misalnya sebagai berikut [5] :

Q : Jumlah yang perlu dipesan untuk pengisian persediaan kembali. $\mathrm{Q}=$ Max - Min

Min : Minimum Stock, adalah jumlah pemakaian selama waktu pesanan pembelian yang dihitung dari perkalian antara waktu pesanan perbulan dan pemakaian rata rata perbulan ditambah dengan persediaan pengaman.

Jadi Min $=(T \times C)+R$

Max : Maximum Stock, adalah jumlah maksimum yang diperbolehkan disimpan dalam persediaan, yaitu jumlah pemakaian selama $2 x$ waktu pesanan, yang dihitung dari perkalian antara $2 \mathrm{x}$ waktu pesanan dan pemakaian rata-rata ditambah dengan persediaan pengaman.

Jadi Max $=(T \times C)+R$

$$
M a x=E O Q+R
$$

Persediaan pengaman : Persediaan ekstra yang harus diadakan untuk proteksi atau pengaman dalam menghindari kehabisan persediaan karena berbagai sebab.

Waktu pemesanan : Waktu yang diperlukan untuk memesan barang.

Perlu ditekankan kembali bahwa penentuan rumus Min-Max, biasanya didasarkan atas formula baku yang dikembangkan sesuai kebutuhan berdasarkan pengalaman perusahaan masing-masing [5].

\section{Sistem Pendukung Keputusan / Decision Support System (DSS)}

DSS merupakan sistem informasi interaktif yang menyediakan informasi pemodelan, dan pemanipulasi data [6]. Menurut Alter dalam [6]. Sistem ini digunakan untuk membantu pengambilan keputusan dan situasi yang tidak terstruktur, dimana tak seorang pun tahu secara pasti bagaimana keputusan seharusnya dibuat. Menurut Turban dalam
[6] tujuan dari DSS adalah

1) Membantu manajer dalam pengambilan keputusan atas masalah semiterstruktur.

2) Memberikan dukungan atas pertimbangan manajer dan bukannya dimaksudkan untuk mengganti fungsi manajer.

3) Meningkatkan efektifitas keputusan yang diambil manajer lebih dari pada perbaikan efisiensinya.

4) Kecepatan komputasi. Komputer memungkinkan para pengambil keputusan untuk melakukan banyak komputasi secara cepat dengan biaya rendah.

5) Peningkatan produktifitas.

6) Dukungan kualitas. Komputer bisa meningkatkan kualitas keputusan yang dibuat.

7) Berdaya saing

8) Mengatasi keterlambatan kognitif dalam pemrosesan dan penyimpanan.

\section{Pengendalian Persediaan}

Persediaan merupakan sumber daya ekonomi yang perlu diadakan dan sisimpan untuk menunjang penyelesaian pengerjaan suatu produk [1]. Fungsi persediaan biasanya berhubungan dengan kegiatan penyediaan bahan-bahan yang dibutuhkan baik jumlah, mutu, waktu maupun tempat dengan memperhitungkan biaya terendah selaras dengan mutu yang direncanakan. Untuk mencapai fungsi tersebut maka dibuatlah suatu pengendalian prsediaan bagi dunia usaha. Pengadaan persediaan umumnya ditunjukan untuk memenuhi hal hal berikut ini [1] :

1) Untuk memelihara independensi operasi.

2) Untuk memenuhi tingkat oermintaan yang bervariasi.

3) Untuk menerima manfaat ekonomi atas pemesanan bahan dalam jumlah

4) tertentu.

5) Untuk menyediakan suatu perlindungan terhadap variasi dalam waktu penyerahan bahan baku.

6) Untuk menunjang fleksibilitas penjadwalan produksi. 
Persediaan Barang dalam penentuannya harus berhati-hati karena hal ini merupakan salah satu daerah keputusan yang perlu diperhitungkan dalam kelangsungan dunia usaha. Kelebihan persediaan akan menyebabkan gangguan dalam perusahaan seperti terjadinya kenaikan biaya penyimpanan bahan baku, menurunnya perolehan laba perusahaan, pengawasan tingkat kerusakan yang lebih tinggi, pembayaran pajak yang lebih, penggunaan modal yang lebih besar [3].

\section{METODE}

Penelitian yang dilaksanakan adalah Penelitian dan Pengembangan (Research and Development / R\&D). Penelitian dan Pengembangan adalah metode penelitian yang digunakan untuk menghasilkan produk tertentu atau mengembangkan produk yang telah ada serta menguji keefektifan produk tersebut. Model yang digunakan dalam membangun pengembangan sistem ini adalah Model Waterfall (air terjun). Model ini menyarankan pendekatan yang bersifat sistematis dan berurutan dalam membangun perangkat lunak, mulai dari tahap analisis, desain, implementasi, evaluasi.

\section{A. Analisis Masalah dan Usulan Solusi}

Proses transaksi penjualan dan pembelian (order) pada Apotek Sahabat Qita dilakukan atau dicatat dalam buku besar atau manual. Pencatatan data stok barang juga dicatat dalam bentuk manual. Proses pembelian (order) dan penyediaan stok barang dihitung dan dipengaruhi dari hasil penjualan barang pada bulan atau periode sebelumnya. Pada Apotek Sahabat Qita menentukan jumlah order atau jumlah pembelian barang ke supplier dari penjualan 2 atau 3 bulan terakhir atau bahkan kurang atau lebih dari 3 bulan.

Masalah pengambilan keputusan dalam menentukan jumlah barang yang harus diorder dan menentukan kapan saatnya melakukan pengorderan barang, karena tidak jarang dalam melakukan pengorderan barang ke supplier pernah mengalami keterlambatan datangnya barang sehingga Apotek Sahabat Qita pernah mengalami kehabisan stok barang. Pencatatan transaksi maupun inventori stok yang masih bersifat tertulis juga sebagai penyebab sulitnya dalam melakukan rekapan data penjualan barang untuk menentukan jumlah pembelian barang pada periode selanjutnya.

Berdasarkan analisis di atas, dengan memanfaatkan teknologi yang berkembang saat ini, dibuat suatu usulan solusi untuk mengatasi permasalahan tersebut. Usulan Solusi yang dimaksud yaitu pembuatan sebuah sistem pendukung keputusan pengendalian persediaan barang menggunakan metode EOQ (Economic Order Quantity) dan MIN MAX berbasis web. Sistem ini dapat mnghitung berapa jumlah barang yang harus dipesan atau dibeli dan menghitung stok minimal yang digunakan untuk pengontrol pemesanan dan stok maksimal sebagai batas penyimpanan barang.

\section{B. Analisis Perangkat Lunak}

Pengembangan sistem pendukung keputusan pengendalian persediaan barang ini memiliki beberapa pengolahan data seperti data barang, supplier, pengguna, penjualan, pembelian (order), barang masuk dan melakukan proses perhitungan pengendalian persediaan seperti jumlah maksimum persediaan, jumlah minimum persediaan dan jumlah pembelian persediaan yang optimal.

Gambaran flowchart dalam proses perhitungan metode EOQ dan Min-max yang akan diimplementasikan sebagai pendukung keputusan pengendalian barang.

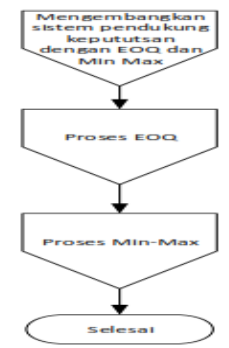

Gambar 1. Flowchart Proses Perangkat Lunak Perhitungan EOQ dan Min-Max 


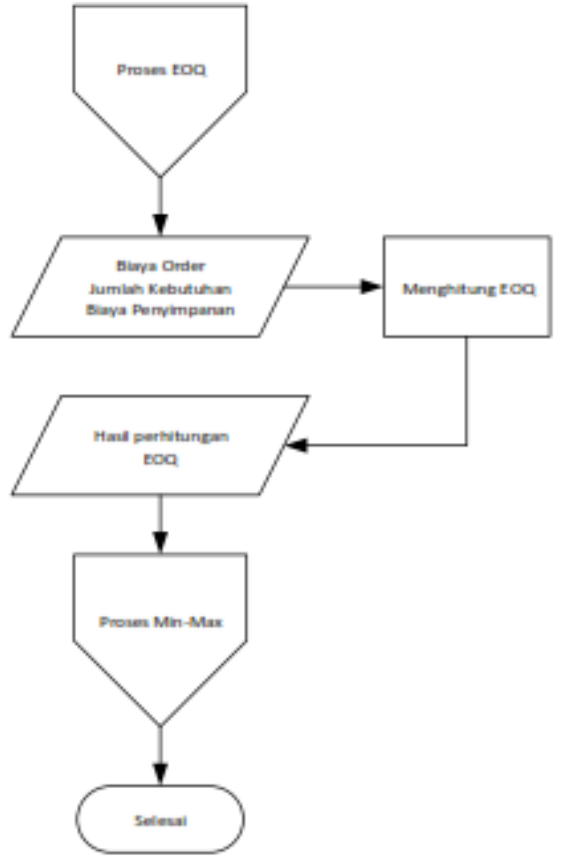

Gambar 2. Flowchart Proses EOQ

Gambar 2 merupakan alur untuk menentukan jumlah pemesanan yang ekonomis dihitung dengan menggunakan metode EOQ. Kemudian hasil dari perhitungan EOQ akan digunakan sebagai data untuk melakukan perhitungan dengan metode Min-Max.

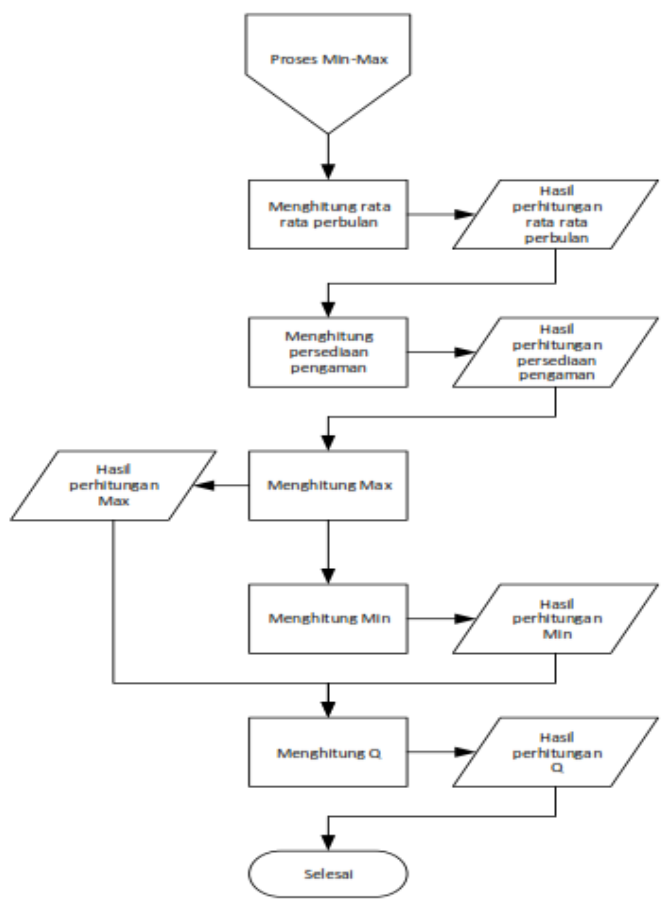

Gambar 3. Flowchart Proses Min-Max
Gambar 3 merupakan alur perhitungan metode Min-Max dengan menggunakan data dari hasil perhitungan EOQ. Hasil perhitungan EOQ digunakan untuk menghitung nilai maksimum dan minimum dengan menggunakan metode Min-Max. Nilai minimum akan dipakai sebagai acuan dalam melakukan pemesanan kembali atau reorder poin dan nilai maksimum sebagai nilai batas tertinggi penyimpanan stok barang.

\section{Perancangan Perangkat Lunak}

Gambaran secara umum terhadap proses interaksi yang terjadi antara perangkat lunak dengan pengguna user dapat dijelaskan menggunakan Use Case Diagram. Use Case Diagram digunakan untuk mewakili fungsionalitas dari sistem. Pengembangan sistem ini terdiri dari 2 pengguna yaitu admin dan pegawai. Admin dapat melakukan hak akses penuh terhadap sistem sedangkan pegawai hanya dapat melakukan beberapa fungsi tertentu dalam sistem.

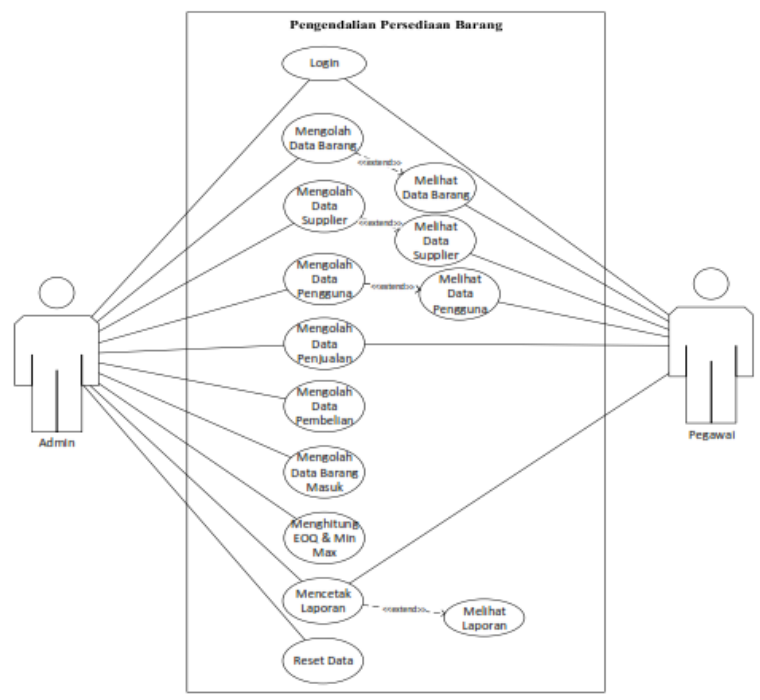

Gambar 4. Use Case Diagram Sistem

Pendukung Keputusan Pengendalian Persediaan Barang Menggunakan Metode EOQ dan Min-Max.

$\begin{array}{ccr}\text { Gambaran } & \begin{array}{c}\text { rancangan } \\ \text { sistem }\end{array} & \begin{array}{r}\text { arsitektur } \\ \text { pendukung }\end{array}\end{array}$


keputusan pengendalian persediaan barang menggunakan metode EOQ dan Min-Max ini dapat dilihat pada Gambar 5.
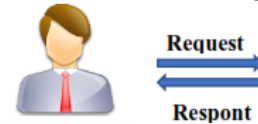

Pengguna

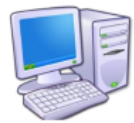
Sistem SPK
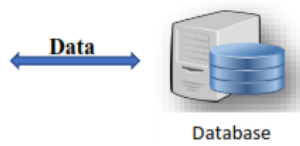

Gambar 5. Arsitektur Sistem Pendukung

Keputusan Pengendalian Persediaan

Barang Menggunakan Metode EOQ dan Min-Max.

\section{HASIL DAN PEMBAHASAN}

A. Implementasi Perangkat Lunak

Implementasi pengembangan sistem pendukung keputusan pengendalian persediaan barang dengan menggabungkan 2 metode sistem permintaan independen yaitu metode EOQ (Economic Order Quantity) dan Min-Max yang dilakukan setelah sebelumnya dilakukan proses perancangan sistem guna merumuskan kerangka dan ruang lingkup sistem yang dibuat. Pengembangan sistem ini diimplementasikan menggunakan bahasa web dengan Framework Laravel 5.3, Atom 1.20.0 (text editor) dan XAMPP Control Panel v3.2.2 sebagai pgeolahan basis data.

Impelemtasi pengembengan ini pada saat dijalankan akan tampil form login sebelum masuk ke menu utama.

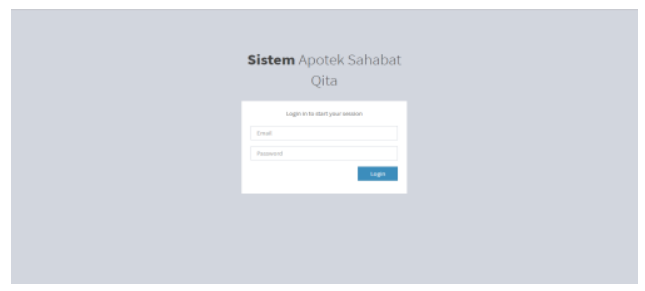

Gambar 6. Form Login

Menu utama sistem dibedakan menjadi 2 yaitu admin dan pegawai, tergambar pada gambar 7 dan 8. Menu utama admin terdapat Data master yaitu data barang, supplier dan pengguna, kemudian data transaksi penjualan dan pembelian (order), data barang masuk, perhitungan EOQ \&Min
Max, laporan dan reset data. Secara umum menu utama admin sama dengan pegawai tetapi di pegawai tidak terdapat menu perhitungan, barang masuk, pembelian dan reset data.
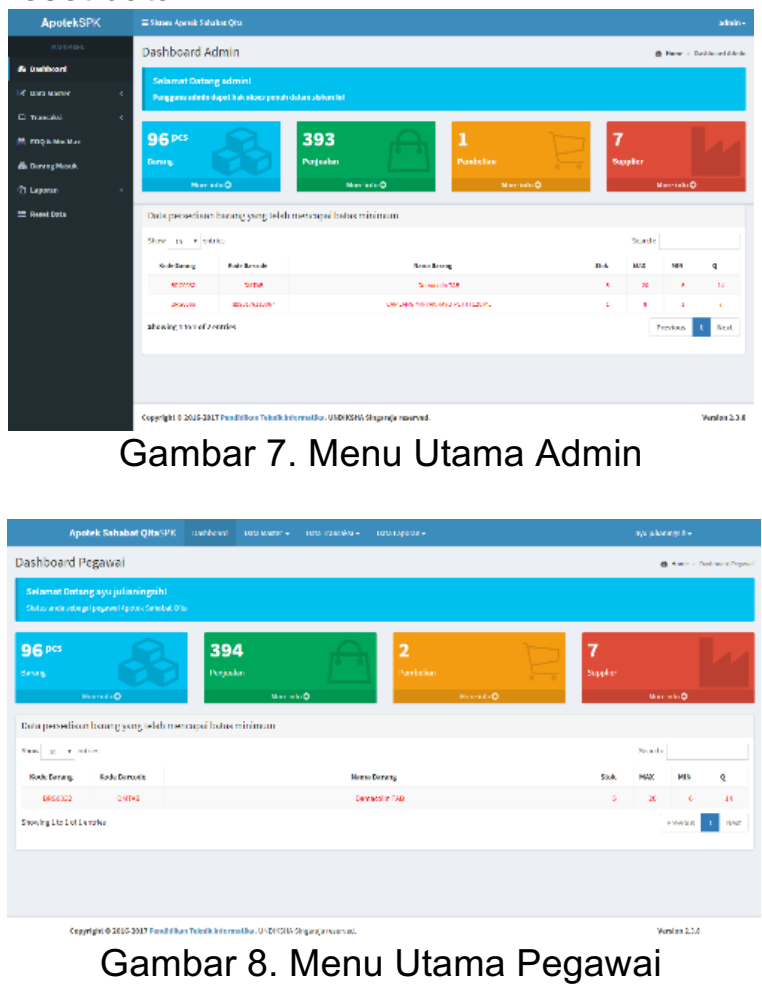

Perhitungan EOQ Min-max dilakukan dengan beberapa langkah yaitu peroses penentuan periode dan jumlah kebutuhan (penjualan) sesuai periode (bulan).

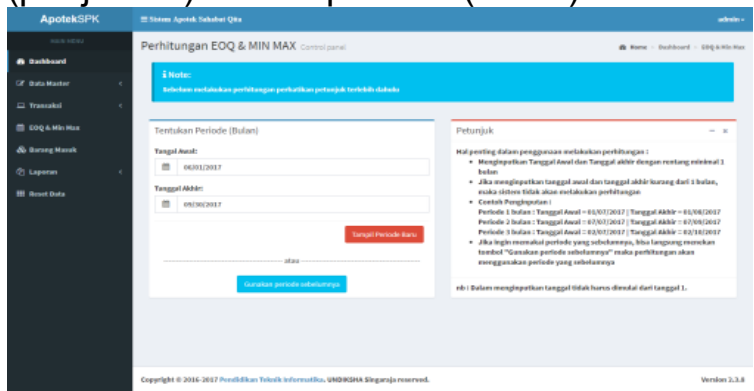

Gambar 9. Penentuan periode (bulan) dan jumlah kebutuhan

Penentuan periode menggunakan data penjualan yang sebelumnya sudah tersimpan. Dengan menginputkan tanggal awal dan tanggal ahir, maka sistem akan melakukan proses penentuan periode (jumlah bulan) dan jumlah kebutuhan dari tanggal yang diinputkan, maka perhitungan 
metode akan dilakukan sesuai dengan gambar 10.

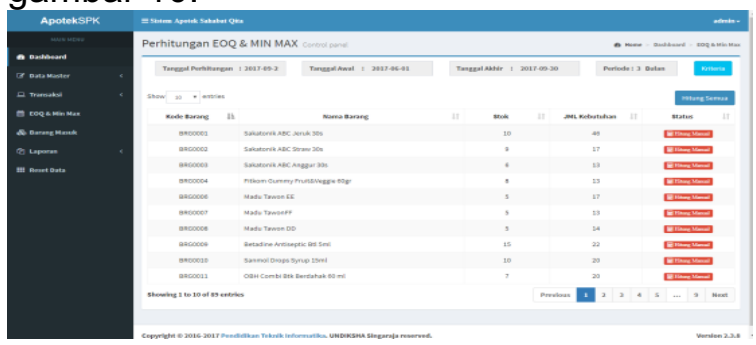

Gambar 10. Form perhitungan EOQ dan Min-Max

Perhitungan metode pada form ini dapat dilakukan dengan memilih barang tertentu yang akan dihitung atau melakukan perhitungan ke seluruh data yang ada. Selain itu pengguna dapat melakukan pengaturan terhadap kriteria yang digunakan dalam perhitungan metode seperti pada gambar 11 .

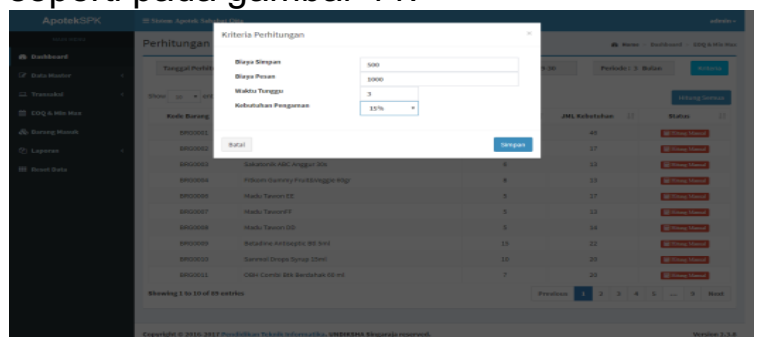

Gambar 11. Form Kriteria Perhtungan

Untuk melengkapi pengambilan data yang digunakan dalam proses perhitungan metode EOQ \& Main max ada beberapa implementasi sebagai form pendukung pengumpulan data untuk proses perhitungan dan sebagai pengolahan datadata dalam proses transaksi penjualan dan pembelian (order) dan laporan.

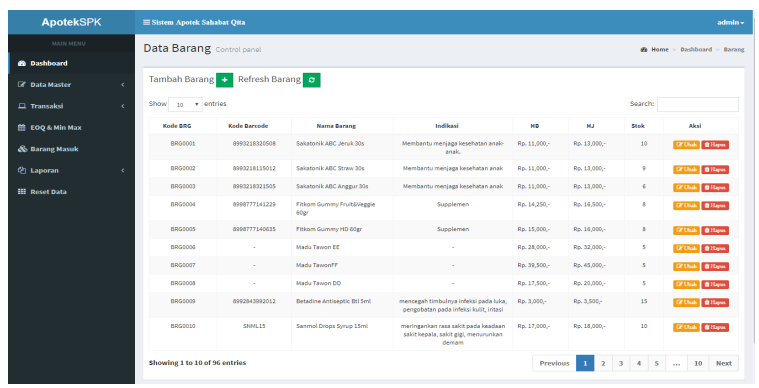

Gambar 12. Form Data Barang

Form Data Barang digunakan untuk melakukan pengolahan data barang. Bagi pengguna admin pada form ini dapat melakukan pengolahan data barang seperti tambah, ubah dan hapus data barang. Sedangkan pengguna pegawai hanya dapat melihat dan melakukan pencarian data barang.

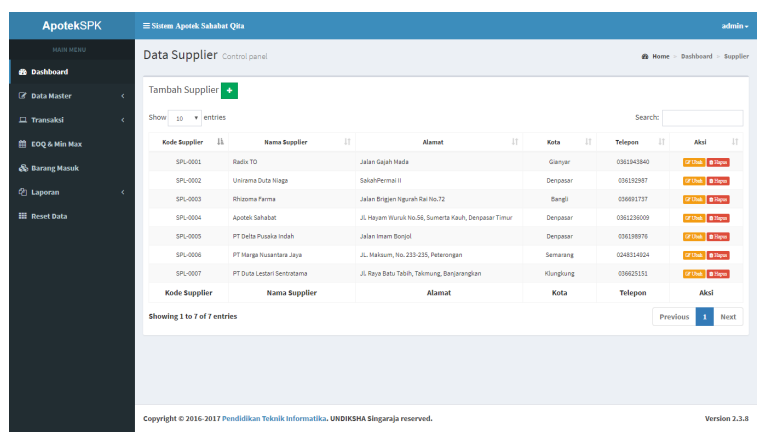

Gambar 13. Form Data Supplier

Form Data Supplier menampilkan data supplier yang bekerja sama dengan Apotek dan disimpan di dalam database. Form Data Supplier ini pengguna bisa melakukan pencarian data supplier berdasarkan kata kunci yang diinputkan, melakukan input atau tambah data, mengubah data supplier dan menghapus data supplier.

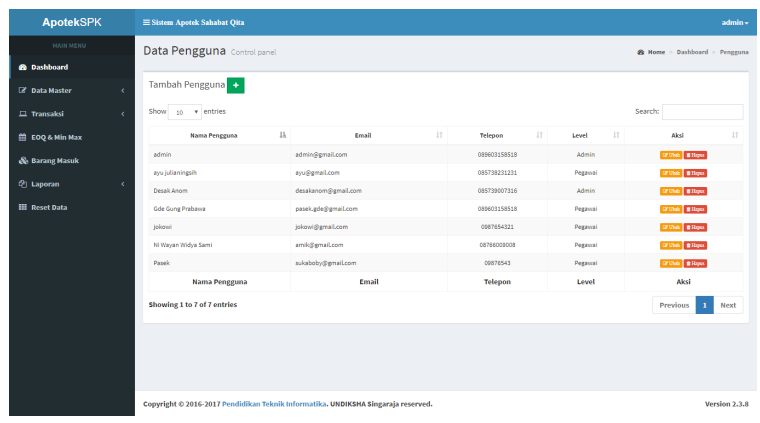

Gambar 14. Form Data Pengguna

Form Data Pengguna menampilkan data pengguna yang terdaftar di Apotek dan disimpan di dalam database. Form Data Pengguna ini pengguna bisa melakukan pencarian data pengguna berdasarkan kata kunci yang diinputkan, melakukan input atau tambah data pengguna, mengubah data pengguna dan menghapus data pengguna. 


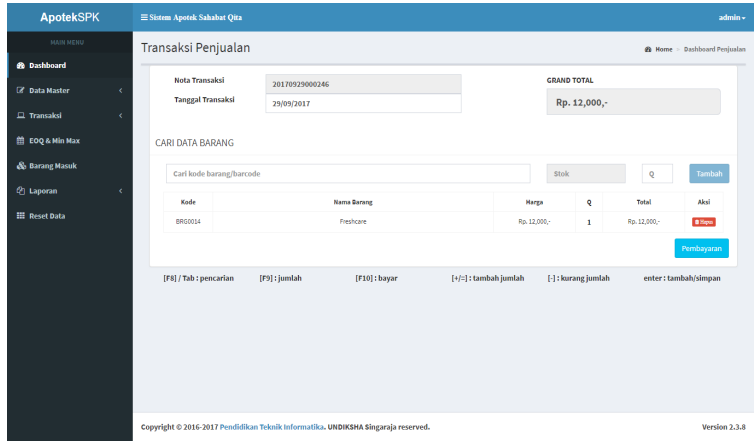

Gambar 15. Form Transaksi Penjualan

Form Transaksi Penjualan digunakan dalam proses penjualan kepada pelanggan. Pengguna dapat melakukan pencarian barang akan dijual, serta mengurangi atau menambah jumlah barang yang akan dijual.

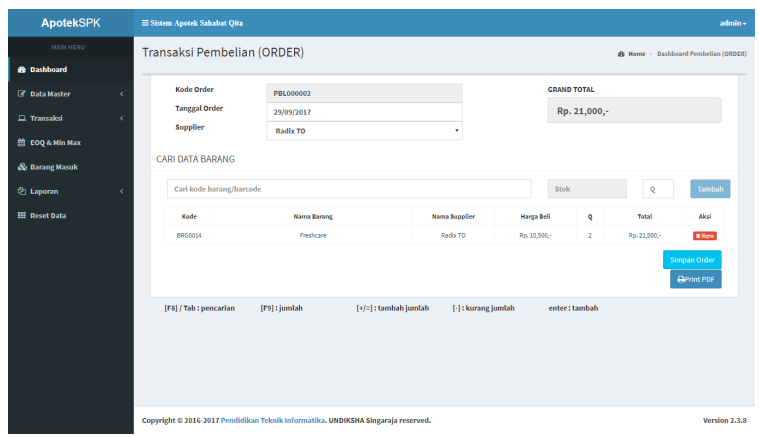

Gambar 16. Form Transaksi Pembelian

Form Transaksi Pembelian (order) digunakan dalam proses pembelian (order) kepada supplier. Pengguna dapat melakukan pencarian barang akan diorder, serta mengurangi atau menambah jumlah barang yang akan diorder. Pengguna juga dapat melakukan cetak data yang diorder sebagai bukti melakukan pemesanan barang ke supplier.

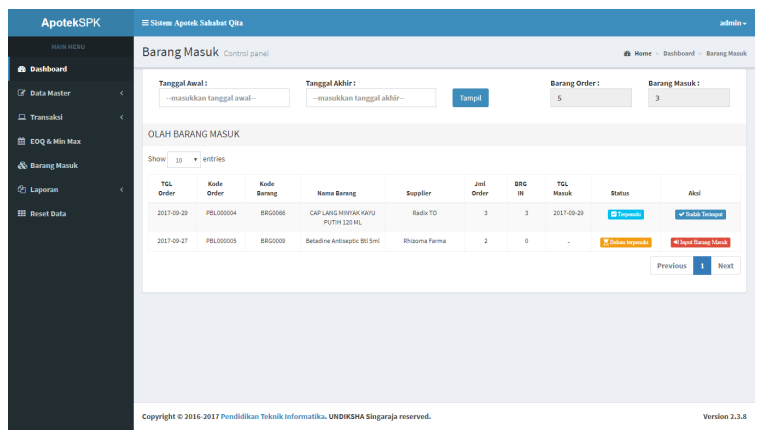

Gambar 17. Form Barang Masuk
Form Barang Masuk digunakan untuk menampilkan barang yang telah diorder dan sebagai tempat untuk melakukan penginputan barang masuk sesuai barang dan tanggal order. Untuk melakukan input barang masuk, dengan menekan tombol input barang sesuai list barang.

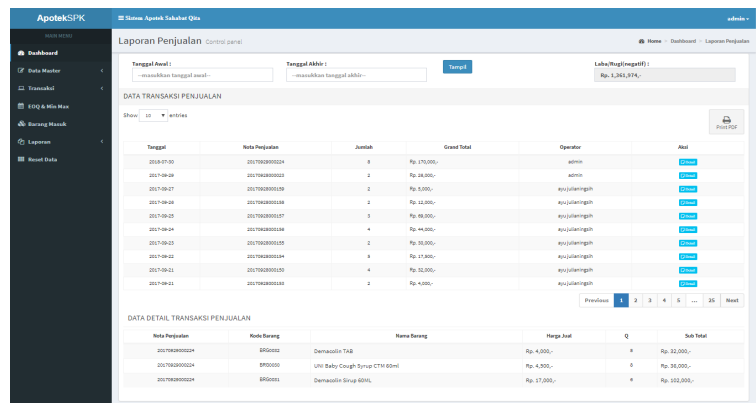

Gambar 18. Form Laporan Penjualan

Form Laporan Penjualan digunakan untuk menampilkan laporan dari keseluruhan data riwayat penjualan ke pelanggan. Pengguna juga dapat melihat riwayat data penjualan sesuai tanggal awal dan tanggal akhir dan dapat melakukan cetak data laporan.

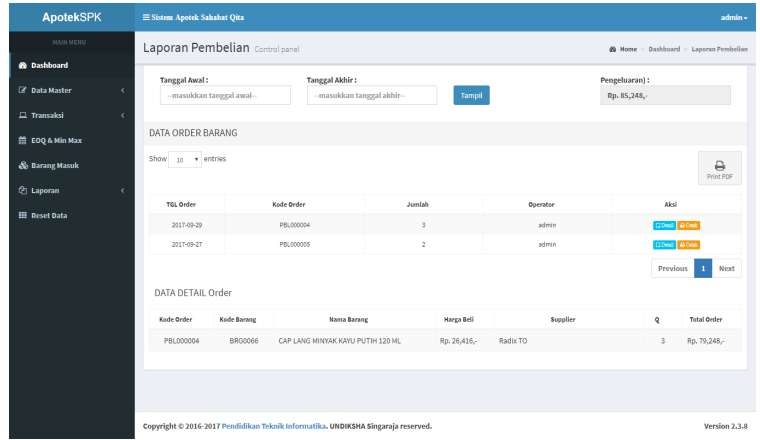

Gambar 19. Form Laporan Pembelian

Form Laporan Pembelian digunakan untuk menampilkan laporan dari keseluruhan data riwayat pembelian ke supplier. Pengguna juga dapat melihat riwayat data pembelian sesuai tanggal awal dan tanggal akhir dan dapat melakukan cetak data laporan. 


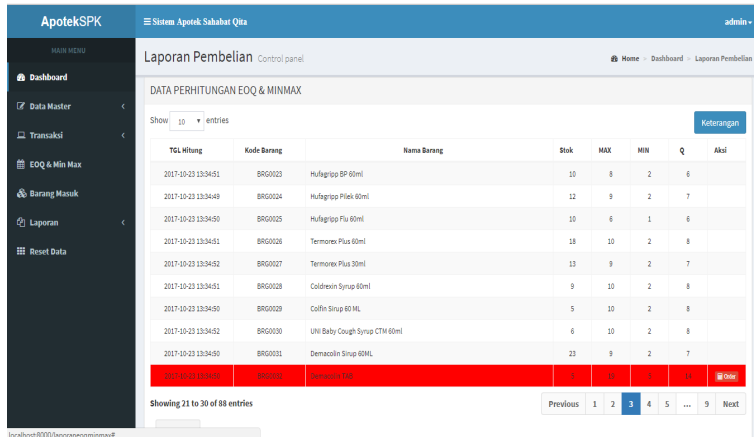

Gambar 20. Form Laporan EOQ \& Min-Max

Form Laporan EOQ \& Min-Max digunakan untuk menampilkan data dari hasil perhitungan EOQ dan Min-Max yang sebelumnya sudah melakukan perhitungan. Data terebut digunakan sebagai rekomendasi dalam melakukan pembelian/pengorderan barang ke supplier, waktu kapan harus melakukan order dan mengontrol persediaan maksimum dan minimum. Form tersebut terdapat beberapa informasi data barang yaitu dengan beberapa field yaitu tanggal perhitungan, kode barang, nama barang, stok, MAX, MIN, Q. Nilai Stok adalah informasi menegenail sisa stok pada setiap barang. Nilai MAX yaitu nilai rekomendasi jumlah maksimal melakukan penyimpanan barang. Nilai MIN yaitu nilai jumlah minimum penyimpanan barang sekaligus sebagai batas waktu melakukan pemesanan (order) barang, sedangkan nilai $Q$ adalah nilai atau jumlah barang yang akan dipesan. Pengguna juga dapat melakukan cetak data dari laporan EOQ \& Min-Max.

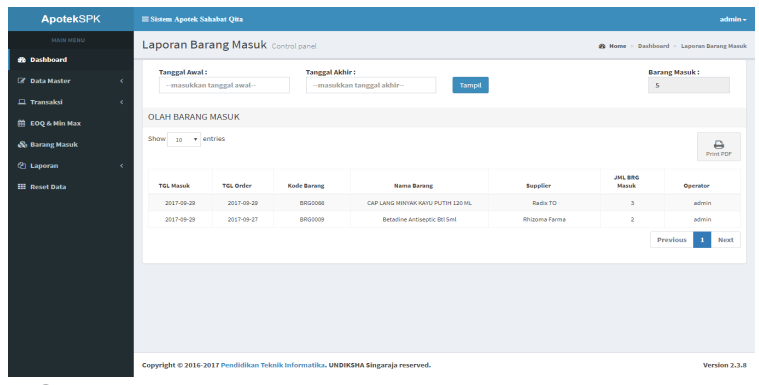

Gambar 21. Form Laporan Barang Masuk

Form Laporan Barang Masuk digunakan untuk menampilkan laporan barang masuk yang telah diinputkan sebelumnya. Pengguna juga bisa melihat data barang masuk sesuai tanggal masuk dengan menginputkan tanggal awal dan tanggal akhir dan pengguna juga dapat melakukan cetak data.

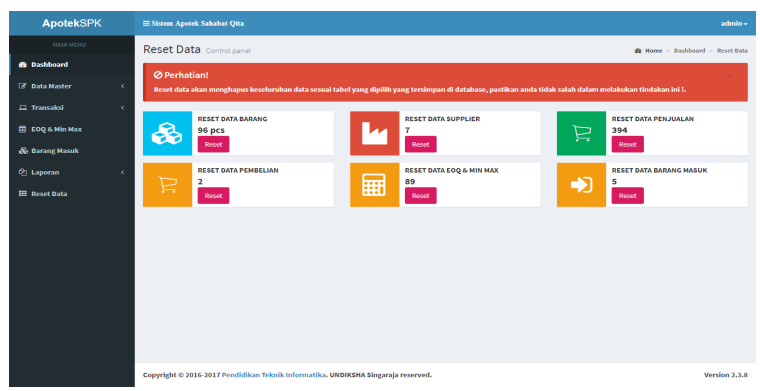

Gambar 22. Form Reset Data

Form Reset Data digunakan untuk melakukan reset atau format data sesuai menu data yang dipilih. Data yang tersimpan akan terformat dari database.

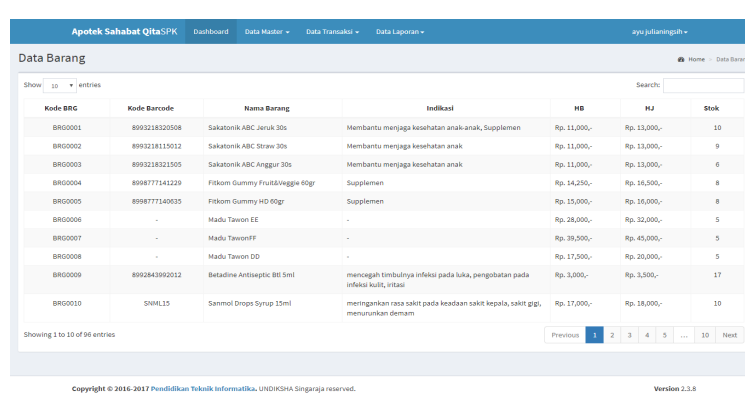

Gambar 23. Form Barang (Pegawai)

Form Data Barang digunakan untuk menampilkan data barang yang tersimpan di database. Pengguna pegawai dapat melakukan pencarian data barang sesuai kata kunci yang dimaksukkan. Pengguna pegawai tidak dapat melakukan insert, update, delete pada data barang.

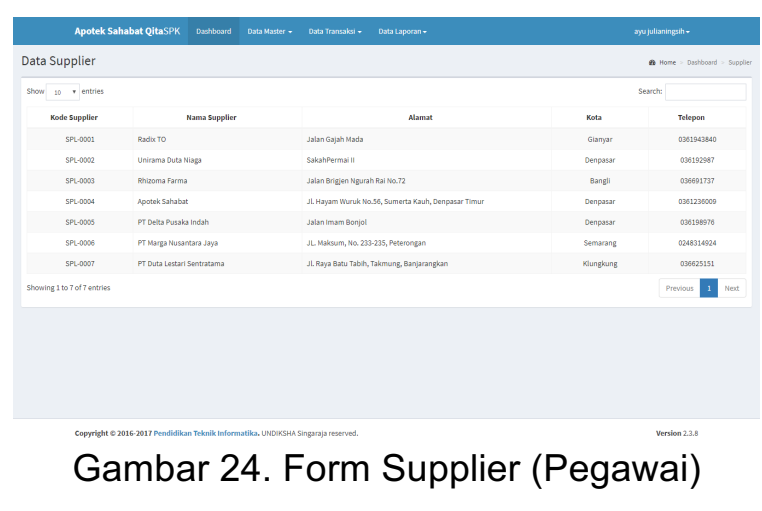


Form Data Supplier (pegawai) digunakan untuk menampilkan data supplier yang tersimpan di database. Pengguna pegawai dapat melakukan pencarian data supplier sesuai kata kunci yang dimaksukkan. Pengguna pegawai tidak dapat melakukan insert, update, delete pada data supplier.

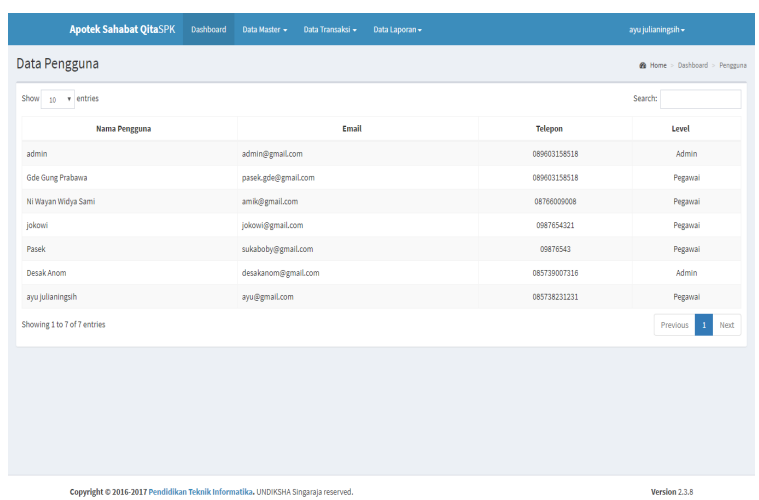

Gambar 25. Form Pengguna (Pegawai)

Form Data Pengguna digunakan untuk menampilkan data pengguna yang tersimpan di database. Pengguna pegawai dapat melakukan pencarian data pengguna sesuai kata kunci yang dimaksukkan. Pengguna pegawai tidak dapat melakukan insert, update, delete pada data pengguna.

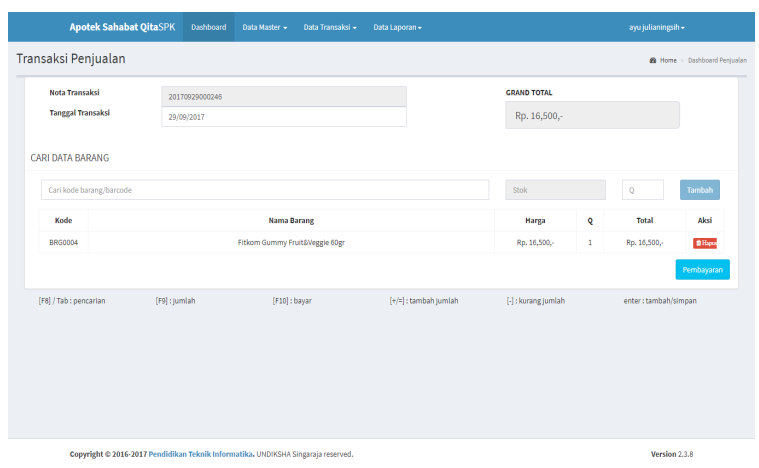

Gambar 26. Form Penjualan (Pegawai)

Form Transaksi Penjualan digunakan untuk melakuka proses transaksi penjualan barang ke pelanggan. Pengguna pegawaidapat melakukan pencarian barang yang akan dijual, menambah dan mengurangi jumlah penjualan barang, menghapus data penjualan barang dan melakukan pembayaran penjualan.

\section{B. Pengujian Perangkat Lunak}

Pengujian yang dilakukan dalam sistem ini dapat di kelompokan menjadi empat pengujian yaitu pengujian fungsional, pengujian konseptual/struktural, uji kesesuaian sistem dan uji respon pengguna. Pelaksanaan pengujian perangkat lunak ini dilakukan pada tanggal 18 September 2017 di Apotek Sahabat Qita Desa Taman Bali Bangli. Dari hasil pengujian fungsional secara umum sudah bisa menangani data masukan yang valid maupun tidak valid dan menampilkan output sesuai yang direncanakan. Hasil pengujian konseptual menunjukkan bahwa sistem telah melaksanakan mekanisme perhitungan dan mekanisme sesuai flowchart pada rancangan yang sudah direncanakan. Pengujian uji kesesuaian yang dilakukan berdasarkan data yang diperoleh di lapangan. Dari barang tersebut diambil data 3 bulan penjualan terakhir, dari bulan Juni 2017 sd Agustus 2017 seperti berikut ini.

Tabel 1. Data Penjualan Demacolin Apotek Sahabat Qita Bulan Juni sd Agustus 2017

\begin{tabular}{|l|l|l|}
\hline Nama Barang & Harga & Jumlah \\
\hline Demacolin & 4000 & 65 \\
\hline
\end{tabular}

1) Menentukan perhtungan $E O Q$

Keterangan :

$$
\mathrm{EOQ}=\frac{\sqrt{2 \times S \times D}}{H}
$$

$S=$ biaya order tiap kali pesan

$\mathrm{D}=$ jumlah kebutuhan periode tertentu

$\mathrm{H}=$ biaya penyimpanan per unit

Dari hasil wawancara kepada pegawai dan owner Apotek Sahabat Qita mengenai kriteria dalam rumus EOQ dan Min-Max didapat bahwa :

a) Biaya Order tiap kali pesan

(S) di Apotek Sahabat

Qita=Rp. 1000.

b) Biaya penyimpanan per unit $(\mathrm{H})=$ Rp. 500 .

c) Kebutuhan Pengaman di Apotek Sahabat Qita ditetapkan $15 \%$ tiap periode. 
Jadi perhitungan EOQ :

$$
\mathrm{EOQ}=\frac{\sqrt{2 \times 100 \times 65}}{500}
$$

2) Penentuan Min-Max

Menghitung Nilai MIN MAX digunakan sebagai waktu pemesanan kembali dan pembatasan dalam penyimpanan persediaan. Namun sebelum melakukan perhitungan MIN MAX akan dilakukan perhitungan-perhitungan lainnya yang mendukung perhitungan MIN MAX, diantaranya sebagai berikut :

a) Rata-rata kebutuhan perbulan

$$
\text { Rata Kebutuhan }=\frac{65}{3}=22
$$

b) Kebutuhan penaman (safety stock) ditetapkan $15 \%$ dari kebutuhan 1 bulan. Kebutuhan Pengaman $=22 \times 15 \%=3$ (dibulatkan)

c) Menghitung waktu tunggu (lead time) ditetapkan 3 hari, dikarenakan kedatangan barang dari waktu order adalah tiga hari kemudian.

d) Waktu tunggu $=3 / 30$ hari $=0,1$.

setelah perhitungan yang sifatnya mendukung proses Min Max dilakukan, kemudian proses Min Max dapat dilakukan.

e) $\mathrm{MAX}=\mathrm{EOQ}+$ Persediaan Pengaman MAX $=16+3=19$

f) MIN = (lead time+ Rata Kebutuhan $)+$ Kebutuhan Pengaman.

$\mathrm{MIN}=(0,1 \times 22)+3=5$

g) Menentukan jumlah yang perlu dipesan $(\mathrm{Q})=$ MAX - MIN

$Q=19-5=14$.

Tabel 2. Hasil Perhitungan Manual

\begin{tabular}{|c|c|c|c|}
\hline $\begin{array}{c}\text { Nama } \\
\text { Barang }\end{array}$ & MAX & MIN & $\mathbf{Q}$ \\
\hline Demacolin & 19 & 5 & 14 \\
\hline
\end{tabular}

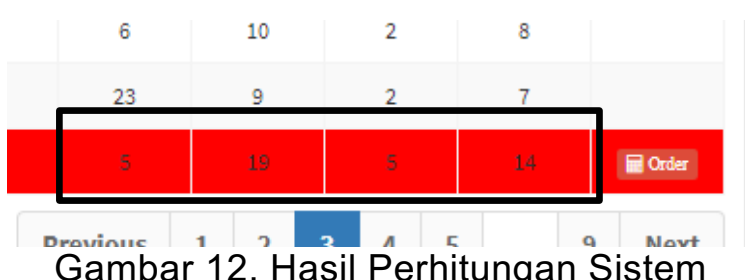

Jadi jika jumlah stok persediaan Demacolin sudah mencapai batas minimum (MIN) maka perlu melakukan pemesanan sejumlah nilai $Q$. Sehingga nilai maksimum (MAX) persediaan selalu menjadi patokan batas penyimpanan untuk meminimalkan biaya penyimpanan dan kerusakan barang.

Dari persamaan diatas dapat dihitung karakteristik lain dari kebijakan optimum sebagai berikut :

1) Total biaya minimum (TIC) :

$$
T I C=\left(\frac{65}{14}\right) 1000+\left(\frac{14}{2}\right) 500=8.143
$$

2) Total biaya pemesanan (TOC) :

$$
T I C=\left(\frac{65}{14}\right) 1000=4,643
$$

3) Total biaya penyimpanan (TCC) :

$$
\text { TCC }=\left(\frac{14}{2}\right) 500=3.500
$$

Perhitungan diatas didapatkan dari hasil perhitungan EOQ \& Min-Max guna mengoptimalkan biaya biaya persediaan seperti biaya pemesanan, biaya penyimpanan dan total biaya minimum.

Pengujian yang terakhir yaitu uji respon pengguna yang dilakukan untuk mengetahui seberapa persen kelayakan kebermanfataan sistem dan mengetahui sistem apakah sudah sesuai dengan permasalahan yang ada dan bisa meminimalisir dari permasalahan yang ada sebelumnya. Pengujian ini ditujukan pada owner atau pemilik dan seluruh pegawai apotek yaitu sebanyak 4 orang, 2 orang admin dan 2 orang pegawai. Hasil dari pengujian respon yang dilakukan ke admin dan pegawai apotek mendapatkan tingkat pencapaian sangat sesuai yaitu dengan persentase $96.6 \%$ dari admin dan 97,3\% dari pegawai dalam tingkat pencapaian kebermanfaatan sistem dalam membantu permasalahan di Apotek Sahabat Qita.

\section{SIMPULAN}

Kesimpulan dari pengembangan sistem pendukung keputusan pengendalian persediaan barang menggunakan metode EOQ (Economic Order Quantity) dan Min- 
max ini adalah 1) Rancangan metode penelitian penelitian pengembangan sistem pendukung keputusan pengendalian persediaan barang menggunakan metode EOQ (Economic Order Quantity) dan Minmax menggunakan metode The Waterfall Model. 2) Sistem ini diimplementasikan menggunakan bahasa Framework Laravel versi 5 beserta composer yang didukung oleh komponen lain seperti XAMPP Control Panel v3.2.2, Atom text editor. 3) Respon pengguna terhadap Pengembangan sistem pendukung keputusan pengendalian persediaan barang menggunakan metode EOQ (Economic Order Quantity) dan Minmax pada Apotek Sahabat Qita mendapat tingkat pencapaian dengan persentase $96.6 \%$ dari admin dan $97,3 \%$ dari pegawai dari tingkat pencapaian kebermanfaatan sistem dalam membantu permasalahan di Apotek Sahabat Qita.

Saran yang dapat diberikan untuk pengembangan lebih lanjut dari penelitian ini adalah diharapkan bisa menyempurnakan dan mengembangkan lebih jauh sehingga menjadi lebih lengkap dan sempurna. 1) Pengembangan sistem pada penelitian ini berbasis web offline, dengan demikian perlu dikembangkan dalam aplikasi sistem pendukung keputusan pengendalian persediaan barang berbasis web online, sehingga laporan order bisa dikirm langsung ke supplier. 2) Pada pengembangan selanjutnya dapat memberikan item discount pada pemesanan dan dapat membuat tampilan yang lebih user friendly kepada pengguna. 3) Pengemban sistem ini hanya memprediksi dengan data penjualan terakhir sesuai periode (bulan) yang ditentukan tanpa memperhitungkan kemungkinan hari raya atau tutup, sehingga perlu dikembangkan sistem SPK dengan memperhitungkan adanya hari raya pada bulan tertentu. 4) Pengembangan ini belum memperhitungkan kadaluarsa suatu barang, sehingga perlu dikembangkan sistem SPK dengan mtode EOQ dan MinMax dengan memperhitungkan kadaluarsa barang.

\section{UCAPAN TERIMAKASIH}

Ucapan terima kasih yang sebesar besarnya kepada owner serta pegawai Apotek sahabat qita yang telah memberikan kesempatan dan motivasi untuk melakukan penelitian di Apotek tersebut serta memberikan dukungan agar penelitian ini selesai tepat waktu.

\section{REFERENSI}

[1] Haming, M., \& Nurnajamuddin, M. Manajemen Produksi Modern Operasi Manufaktur dan Jasa Buku 2.Jakarta: Bumi Aksara. 2013.

[2] Fatona, E. Pengembangan Aplikasi Sistem Pendukung Keputusan Pengontrol Persediaan dan Jumlah Pembelian Barang Menggunakan Metode EOQ (Economic Order Quantity) Studi Kasus di Perusahaan Wjes Frozen Food SIngaraja. KARMAPATI. 2013; 2(1): 317-331.

[3] Gitosudarmo, I., \& Mulyono, A. Manajemen Bisnis Logistik. Yogyakarta: BPFE. tahun: 2014

[4] Setiawan, A. B., \& Rohman, F. (2015). Sistem Pengendalian Persediaan Bahan Baku Menggunakan Metode Eoq ( Economic Order Quantity ) Di Sentra Produksi Krupuk Kabupaten Kediri. STMIK AMIKOM. 2015; 3(7): 19-24.

[5] Indrajit, E., \& Djokopranoto. (2004). Dari MRP Material Requirement Planning menuju ERP Enterprise Resource Planning. . Diambil kembali dari Scribd:(https://www.scribd.com/doc/734 57609/Dari-MRP-Material-RequirementPlanning-Menuju-ERP-EnterpriseResource-Planning)

[6] Kusrini. Konsep dan Aplikasi Sistem Pendukung Keputusan. Yogyakarta: ANDI.

[7] Riadi, M. (2013). Sistem Pendukung Keputusan (SPK). Diambil kembali dari http://www.kajianpustaka.com/2013/09/s istem-pendukung-keputusan-spk.html

[8] Rianti, R., Anak, A. G., \& Fitri, S. (2016). Perhitungan Persediaan Bahan Baku dengan Metode Economic Order Quantity Berdasarkan Varian Produk (Studi Kasus : CV Dwi Sumber, 
Semarang).JNANAPATI.2015; 5(1): 3239.

[9] Sibarani, E., Bu'ulolo, F., \& Sebayang, D. (2013). Penggunaan Metode EOQ dan EPQ Dalam Meminimumkan Biaya Persediaan Minyak Sawit Mentah (CPO). Saintia Matematika. 2013; 1(4): 338- 347.

[10] Yahya, K., \& Nasaruffin. (2013). Sistem Pendukung Keputusan Penentuan Persediaan Bahan Baku (Studi Kasus : PT. Makasar Megaprima). InfoSys Journal. 2013; 2(1): 64-79.

[11] Dio, P. H. (2012). Konsep Persediaan Minimum-Maksimum. Optimasi Sistem Industri. 203-207.

[12] Indroprasto, E. S. (2012). Analisis Pengendalian Persediaan Produk dengan Metode EOQ Menggunakan Alhoritma Genetika untuk Mengefisiensi Biaya Persediaan. Jurnal Teknik ITS. 2012;1;305-309. 